\title{
Črtová emocionálna inteligencia a životná spokojnost vysokoškolákov - kroskulturálny výskum (Slováci vs. Ukrajinci)
}

\section{Trait Emotional Intelligence and Life}

Satisfaction of University Students Cross-cultural Research (Slovaks vs. Ukrainians)

Lada Kaliská, Lucia Pašková, Vladimír Salbot

Katedra psychológie, Pedagogická fakulta, Univerzita Mateja Bela

Abstrakt Štúdia analyzuje rozdiely a predikciu črtovej emocionálnej inteligencie Petridesa (2009, d’alej EI) a jej faktorov (well-beingu, sebakontroly, emocionality, sociability) vo vzt’ahu k životnej spokojnosti podl’a Dienera (2000) u vysokoškolákov v kros-kultúrnom výskume (Ukrajinci [N=93; $47.3 \%$ mužov, Mvek=21.6, $S D=2.8]$ vs. Slováci [N=100; $51.8 \%$ mužov, Mvek=20.1, SD=1.4]). Črtová EI bola posúdená Dotazníkom črtovej emocionálnej inteligencie-krátka forma (TEIQue-SF, Petrides, 2009) a životná spokojnost' škálou životnej spokojnosti Satisfaction with life scale (SWLS, Diener, Emmons, Larsen, \& Griffin 1985). Metodiky boli adaptované na kultúrne prostredie. Signifikantné kros-kultúrne rozdiely na hranici strednej vecnej významnosti sa preukázali v celkovej životnej spokojnosti ( $t=2.68, p \leq .01 ; d=.39)$ a len vo faktore well-beingu $z$ črtovej EI $(t=2.02, p \leq .05 ; d=.29)$ $\mathrm{s}$ vyšším skóre pre slovenských študentov. Črtová EI vstupuje do vysoko signifikantného vztahu v oboch skupinách so životnou spokojnostou a umožňuje predikovat’ istú mieru variability v oboch skupinách (u Ukrajincov do $47 \%$ [F $(1,91)=82.63$, p $\leq .001]$ a u Slovákov do rozsahu $20 \%[\mathrm{~F}(1,99)=25.94, \mathrm{p} \leq .001])$. Jediným signifikantným prediktorom v obidvoch skupinách pri kontrole všetkých faktorov črtovej EI bol faktor well-being, ktorý zostal v signifikantnom silnom vzt’ahu s celkovou životnou spokojnostou ( $\mathrm{r}=.56, \mathrm{p} \leq .001)$. 
Štúdia zdôrazňuje facilitáciu celkovej životnej spokojnosti determinovanej sociálnymi okolnostami ako možnost̉ami zvyšovania úrovne mentálneho zdravia.

Klúčové slová životná spokojnost', črtová emocionálna inteligencia a jej faktory, TEIQue-SF, SWLS, kros-kultúrne porovnanie, predikcia.

Abstract Introduction: Promotion of mental health, prevention and treatment of mental disorders was accepted by WHO, the European Commission and the Council of Europe as their priority in the form of the European Declaration for Mental Health. This declaration is also elaborated in the WHO Action Plan for the European Commission (Health 2020, WHO 2015). These facts become a challenge for psychology in the 21st century, whose main goal is to convey, develop and teach individuals' life skills enabling them to "survive", so that they can effectively cope with life circumstances and become satisfied with their lives. It is beyond obvious, and supported by several researches, that life satisfaction is determined also by the social circumstances and conditions. Generation $\mathrm{Z}$ (born 1995-2010) and Generation Alfa (born after 2010) are the wisest generations there have been up to now; knowing more than any other generation, they have access to information on a global scale, but they seem to lack basic life skills to support their own mental health. One of the possibilities is to support facilitation of trait emotional intelligence facets (EI). Our main interest is reflected in trait EI by K.V. Petrides whose EI conceptualization and EI tools for three developmental stages (children, adolescents, adults) were standardized for the Slovak conditions. This model has empirically proved its incremental validity in predicting such variables as life satisfaction, happiness, stress management at work, depression, negative event ruminations, adaptive and maladaptive coping strategies etc. (Kluemper, 2008; Petrides, Perez-Gonzalez, \& Furnham, 2007; Petrides, 2009; Russo et al., 2012). In our cultural environment, it was verified with such variables as respondents' overall health, depression, anxiety, post-traumatic stress disorder, general self-efficacy or coping strategies (Kaliská, Heinzová, \& Nábělková, 2019). It consists of 15 facets forming four factors (well-being, self-control, emotionality, sociability) and global trait EI level.

Goal: The aim was to analyze cross-cultural differences and prediction of trait EI level and its four factors in two nationalities, Slovak and Ukrainian university students, in relation to Diener's life-satisfaction concept (2000). Diener categorized life satisfaction under subjective well-being construct differentiating four individual components: 1) life satisfaction (cognitive part as an information-based appraisal of individual's life in relation to an envisioned (ideal' life), 2) life satisfaction with important life aspects, 3) positive affect as hedonic evaluation guided by emotions and feelings, and 4) absence of negative affect. Methods: Research groups comprised Ukrainian university students from various universities in Kyjev, Ukraine ( $\mathrm{N}=93 ; 47.3 \%$ of males, Mage=21.6 years, /SD=2.8/) and Slovak university students from Matej Bel University in Banska Bystrica, Slovakia (N=100; 51.8 \% of males, Mage=20.1 years /SD=1.4). Trait EI was assessed by Trait Emotional Intelligence Questionnaire-Short Form (TEIQue-SF; Petrides 2009) and life satisfaction by the Satisfaction with life scale (SWLS, Diener, Emmons, Larsen, \& Griffin, 1985). Both tools were modified and adapted to local conditions. 
Results: T-test analysis and effect size estimation proved a higher level of life satisfaction with medium effect size for the Slovaks in comparison to the Ukrainians ( $t=2.68$, $\mathrm{p} \leq .01 ; \mathrm{d}=.39$ ), and only well-being factor significant differences with medium effect size $(t=2.02, p \leq .05 ; d=.29)$ also in favor of the Slovaks. Correlation and regression analysis revealed that higher level of trait EI and its factors was significantly strongly related to a higher level of life satisfaction, especially in the Ukrainian group. In the Slovak group, the strongest significant relations were between well-being, self-control and global level of trait EI and life satisfaction. Global trait EI level predicted significantly to a certain extent life satisfaction in both groups (for the Ukrainians it was $47 \%, \mathrm{~F}(1,91)=82.63, \mathrm{p} \leq .001$ ), for the Slovaks it was $20 \%, \mathrm{~F}(1,99)=25.94, \mathrm{p} \leq .001)$. Well-being was the only significant strong predictor in both groups $(\mathrm{r}=.56, \mathrm{p} \leq .001)$ whilst controlling for the other EI factors.

Conclusion: The study emphasizes the need to educate, facilitate and support any man's emotion-related personality traits, especially well-being attitude towards life determined by social life circumstances, as a form of mental health prevention.

Keywords mental health, trait emotional intelligence, life satisfaction, Ukraine university students from Ukraine, Slovak university students from Slovakia. 
Posudzovanie mentálneho zdravia v celosvetovom meradle kontinuálne od roku 2000 sa stalo hlavnou prioritou Svetovej zdravotníckej organizácie (WHO, 2019), kde je zdôraznené, že práve násilie, chudoba a ponižovanie zvyšujú riziko vzniku problémov v oblasti mentálneho zdravia (WHO, 2015). Správa WHO z r. 2015 uvádza, že v roku 2012 zahynulo viac ako 1,3 milióna adolescentov $\mathrm{v}$ dôsledku ochorení, ktorým sa dalo predíst' alebo ich bolo možné liečit'. Viac ako polovica všetkých duševných porúch v dospelosti sa začína pred 14 rokom života človeka. Podporu mentálneho zdravia, prevenciu a liečenie duševných porúch prijali reprezentanti WHO, Európskej komisie i Rady Európy ako svoju prioritu v podobe Európskej deklarácie mentálneho zdravia (European Declaration for Mental Health). Uvedená deklarácia je rozpracovaná do akčného plánu WHO pre Európsku komisiu (Health 2020, WHO, 2015).

Tieto skutočnosti sa stávajú výzvou pre psychológov v 21. storočí, kde hlavným ciel'om je sprostredkovat', rozvíjat' a rozvinút u jednotlivcov zručnosti, ktoré im umožnia „prežit“ tak, aby sa dokázali vyrovnat so životnými okolnostami a aby boli spokojní so svojim životom. Generácia Z (narodená v rokoch 1995-2010) a generácia Alfa (narodená po roku 2010) je doposial' generáciou s najväčším dosahom na informácie v celosvetovom meradle, avšak ako sa zdá, chýbajú im základné spôsobilosti ako chránit', facilitovat', rozvíjat', či posilňovat’ vlastné mentálne zdravie.

Jednu $\mathrm{z}$ možností vidíme $\mathrm{v}$ podpore facilitovania aspektov črtovej emocionálnej inteligencie, kde sa v zahraničí empiricky preukázala jej prírastková validita pri predikcii takých kriteriálnych premenných ako je životná spokojnost', štłastie, zvládanie pracovnej zátaže, depresia, ruminácie negatívnych udalostí, či adaptívne a maladaptívne copingové stratégie (Petrides et al., 2007; Kluemper, 2008; Petrides, 2009; Russo et al., 2012 a i.) a v našom kultúrnom prostredí s premennými ako celkové zdravie respondenta, depresia, úzkostnost', post-traumatická stresová porucha, všeobecná vnímaná sebaúčinnosť či zvládacie stratégie (Kaliská et al., 2019).

\section{Emocionálna inteligencia}

Problematika emocionálnej inteligencie (EI) nestráca na svojej popularite ani v priebehu svojej 30 ročnej existencie (od vzniku v r. 1990 Mayer a Salovey) a neustále vyvoláva záujem odborníkov, profesionálov, či výskumníkov, a v neposlednom rade i širokej verejnosti, populistov, novinárov, ktorí chcú t’ažit $\mathrm{z}$ atraktívnosti samotného pojmu a slubujú „zaručený úspech“ $v$ živote v podobe merania a rozvíjania EI. V psychologickej teórii sa tak sformovali dva základné prístupy k skúmaniu EI. Prvý z nich prestavuje EI ako schopnost', ktorú je možné merat testami maximálneho výkonu (performance measures) ako tradičnú inteligenciu. Druhý prístup spája EI s osobnostou, konkrétne s dispozíciami správat’ sa určitým - emocionálne kompetentným - spôsobom. V tomto prípade sa používa pojem črtová emocionálna inteligencia a nástroje na jej meranie majú charakter sebapopisných, sebavýpoved’ových nástrojov (self-report measures). Práve model črtovej EI anglického 
psychológa Petridesa (2009) sa stal predmetom nášho dlhodobého overovania, čo vyústilo do kreovania štandardizovaných dotazníkov v dvoch formách (dlhej a krátkej) a troch verziách na meranie špecifík troch vývinových období (detstvo, adolescencia, dospelost'). Jedna z najpoprednejších databáz Web of Science Core Collection Index database (WoS) evidujúca vedecké práce od roku 1945 do súčasnosti uvádza 8403 rôznych zdrojov, ktoré pojednávajú o problematike EI v jej rôznych súvislostiach (WoS, november, 2019). Tendencia analyzovat rôzne koncepcie EI v kontexte životnej spokojnosti u rôznych skupín bola zaznamenaná v 279 vedecko-výskumných štúdiách, pričom len $49 \mathrm{z}$ nich analyzuje súvislosti črtovej EI a životnej spokojnosti. Len $1 \mathrm{z}$ nich sa zameriava na nami verifikovaný model črtovej EI Petridesa (2009) s akcentom na verifikovanie kriteriálnej a prírastkovej validity tohto modelu (Petrides et al., 2007). Našu štúdiu je taktiež možné posudzovat' ako súčast' rozsiahleho a dlhodobého procesu validizácie daného konštruktu s akcentom na tzv. súbežnú validitu, ktorá zistuje, či výskumný nástroj (na meranie črtovej EI) dobre koreluje s iným nástrojom (na meranie životnej spokojnosti) na základe predpokladu, že oba merajú totožný konštrukt.

Model črtovej emocionálnej inteligencie (Trait Emotional Intelligence - EI) Petridesa (2009) je prvým systematickým modelom črtovej EI. Tvorí ho 15 komponentov, kde 13 z nich vytvára štyri všeobecnejšie faktory a dva samostatne stojace faktory. Každý komponent reflektuje určitú osobnostnú vlastnost’ vztahujúcu sa k emocionálnemu prežívaniu jednotlivca. Petridesov črtový model EI pozostáva $z$ nasledujúcich faktorov.

1. Well-being zahŕňa osobnostné črty spojené s prežívaním subjektívnej pohody. Patria sem komponenty: optimizmus, črtové štastie a sebaúcta.

2. Emocionalita zahŕňa účinnost’ pri vnímaní a vyjadrovaní emócií. Patria sem komponenty: črtová empatia, percepcia emócií, expresia emócií a vztahová kompetencia.

3. Sociabilita je tvorená emocionálnou účinnostou v oblasti sociálnych interakcií, pri riadení a usmerňovaní emócií iných. Patria sem komponenty: manažment emócií (druhých), asertivita a sociálna uvedomelost'.

4. Sebakontrola obsahuje aspekty vlastnej účinnosti pri regulovaní emócií a impulzov. Patria sem komponenty: emocionálna regulácia, (nízka) impulzivita a zvládanie stresu.

Samostatnými emocionálnymi komponentmi v Petridesovom modeli črtovej EI sú adaptabilita a sebamotivácia (spracované podl'a: Petrides, 2009; Kaliská \& Nábělková, 2015).

\section{Životná spokojnost}

Analýze životnej spokojnosti a s ňou súvisiacich konštruktov sa v poslednej dobe venuje značná pozornost'. Spokojnost’ s vlastným životom tvorí neoddelitel'nú súčast' subjektívnej pohody (subjective well-being), ktorá je zároveň vel'mi často považovaná za indikátor kvality života (quality of life). Vo viacerých vymedzeniach pojmu kvalita života sa stretávame s dôrazom kladeným na spokojnost'. Podl’a tohto ponímania žije kvalitne ten, kto je 
so svojím životom spokojný. Jednotlivec býva spokojný vtedy, ked' sa mu darí dosahovat' vopred stanovené ciele. Echteld (in Ellison, 1991) chápe toto uspokojenie ako dôsledok dlhodobej skúsenosti daného človeka s dosahovaním svojich životných ciel'ov. Ked' sa človeku darí realizovat' vlastné plány, je spokojný. To znamená, že miera spokojnosti má úzky vztảa k osobnému chápaniu kvality života. V zameraní na výskum subjektívnej pohody je najpreferovanejšou Dienerova koncepcia (2002, 2004), podla ktorej bola subjektívna pohoda tvorená tradične dvoma komponentmi:

1. Emocionálny komponent - frekvencia prežívania pozitívnych a negatívnych emócií.

2. Kognitívno-evaluatívny komponent - spokojnost' so svojím životom.

Emocionálny komponent vychádza $\mathrm{z}$ kruhového modelu afektívnych reakcií, ktorý rozlišuje dve dimenzie:

1. pozitívne emócie (reprezentujú ju adjektíva pozitívnych emócií - naradostený, aktívny...), 2. negatívne emócie (reprezentujú ju adjektíva negatívnych emócií - ustráchaný, nahnevaný...) (Watson, Clark, \& Tellegen, 1988). Uvedený komponent je meraný prostredníctvom výpovede osoby o frekvencii prežívania jednotlivých emócií a funguje na princípe homeostázy (prípadná zmena je korigovaná na pôvodnú úroveň, ktorá je pre danú osobu typická).

Kognitívny komponent (obsah je takmer identický s pojmom životná spokojnost’ a funguje na princípe psychického ekvilibra - po prípadnej zmene sa môže stabilizovataj na inej úrovni). Tento komponent je meraný na základe výpovede osoby, ktorá prostredníctvom kognitívnych procesov hodnotí, ako je spokojná so svojím životom v celku a v jeho rozličných - špecifických oblastiach. Fahrenberg (1994) napríklad charakterizuje životnú spokojnost’ ako individuálne hodnotenie minulých a súčasných podmienok života a očakávanej životnej perspektívy. Uvedený autor rozlišuje spokojnost’ so životom ako celkom a okrem toho aj spokojnost’ s týmito špecifickými oblastami života každého z nás: zdravie, práca a povolanie, finančná situácia, vol’ný čas, manželstvo a partnerstvo, vzt̉ah k vlastným detom, spokojnost’ s vlastnou osobou, sexualita, priatelia, známi a príbuzní, bývanie.

Zistenia Dienera et al. (1994; 1999; 2000 a pod.) naznačujú, že spokojnost’ so životom ako súčast' subjektívnej pohody reflektuje napíňanie jedincových hodnôt a cielov a podiel’a sa na hl'adaní zmysluplnosti jeho života. Džuka a Dalbertová (2002; 2006) uvádzajú, že spokojnost’ je $\mathrm{v}$ rámci psychológie l’udských potrieb a v rámci teórie samoregulácie oblastou psychických javov, ktorú zarad’ujeme do subjektívnej zážitkovej sféry človeka. Je to subjektívny zážitok, ktorý u človeka vzniká v súvislosti s objektívne existujúcimi potrebami, alebo podla teórie samoregulácie ako odpoved' na autoregulačné procesy v organizme. V našom príspevku vychádzame zo súčasnej Dienerovej koncepcie (2000) subjektívnej pohody, kde autor rozlišuje štyri samostatné komponenty:

1. Životná spokojnost' (kognitívna zložka, ide o globálne posúdenie svojho života).

2. Životná spokojnost's dôležitými doménami života (napr. pracovná spokojnost'). 
3. Pozitívny afekt (prežívanie viac radostných emócií a nálad).

4. Nízka úroveň negatívneho afektu (prežívanie malého počtu neradostných emócií a nálad).

Na posúdenie globálnej úrovne životnej spokojnosti zostrojili autori Diener, Emmons, Larsen a Griffin (1985) škálu pod názvom Satisfaction with life scale (SWLS, 1985).

\section{Emocionálna inteligencia a životná spokojnost}

Palmer, Donaldson a Stough (2002) skúmali vzţah medzi črtovou EI a životnou spokojnostou na vzorke 107 respondentov. Vekové rozpätie vzorky sa pohybovalo od 16 do 64 rokov. Na skúmanie črtovej EI bola použitá modifikovaná verzia Trait-Meta-Mood Scale (TMMS) od autorov Salovey a Mayer (1990). Metodika obsahuje 3 subškály: všímanie si emócií, jasnost' emócií a náprava (regulácia emócií). Na zistovanie životnej spokojnosti bola použitá škála SWLS od Dienera et al. (1985). Škála meria celkovú životnú spokojnost'. Autori zistili štatisticky vysoko významnú stredne silnú koreláciu medzi jasnostou emócií a celkovou životnou spokojnostou ( $\mathrm{r}=.45 ; \mathrm{p}<.001)$. Ostatné subškály vstupovali len do slabých nevýznamných korelácií. Výskum podobného charakteru realizovali Extremera a Fernández-Berrocal (2005). Aj oni pracovali so škálami TMMS a SWLS. V tomto prípade výskumnú vzorku tvorili vysokoškolskí študenti Univerzity v Malage $(\mathrm{n}=186)$. Štatisticky významne korelovali subškála jasnost’ emócií a životná spokojnost’ ( $\mathrm{r}=.35$, $\mathrm{p}<.01)$, ale aj regulácia emócií a životná spokojnost' $(\mathrm{r}=.41, \mathrm{p}<.01)$. Na vzorke rumunských vysokoškolákov ( $n$ = 131, 103 žien a 28 mužov, priemerný vek 23.18) skúmali vztahy medzi črtovou EI a životnou spokojnostou Runcan a Iovu (2013). Na zistovanie črtovej EI použili Wongovu a Lawovu škálu emocionálnej inteligencie (WLEIS, 2002). Životnú spokojnost skúmali škálou SWLS (Diener et al., 1985). Ako mediátory vzt̉ahu medzi EI a životnou spokojnostou boli použité Rosenbergova škála sebahodnotenia a Multi-dimenzionálna škála vnímanej sociálnej opory. Bootstrap analýza ukázala, že sebahodnotenie a sociálna opora čiastočne sprostredkovali vzt̉ah medzi črtovou EI a životnou spokojnostou. Španielski autori Urquijo, Extremera a Villa (2015) skúmali, okrem iného, aj vztah medzi životnou spokojnostou a črtovou EI. Použili Wongovu a Lawovu škálu emocionálnej inteligencie (WLEIS, 2002) a Dienerovu škálu životnej spokojnosti (SWLS, 1985). Výskumnú vzorku tvorilo 400 absolventov (278 žien a 122 mužov vo veku od 22 do 60 rokov) z Univerzity v Dueste. Korelácia medzi životnou spokojnost’ou a črtovou EI bola $\mathrm{r}=.44(\mathrm{p}<.01)$. Ďalší výskum, pochádza od iránskych autorov Foumany a Salehy (2015), ktorí skúmali vzt̉ah medzi EI a životnou spokojnostou a úlohu mediátorov predstavovali reziliencia a emocionálna harmónia. Bola použitá Shearingova škála emocionálnej inteligencie (obsahuje 33 položiek), Dienerova škála životnej spokojnosti, Škála emocionálnej harmónie (PANAS), Connerova a Davidsonova škála reziliencie. Výskumu sa zúčastnilo 250 študentov $\mathrm{z}$ Univerzity Zanjan vo veku od 20 do 25 rokov (68 \% žien). Za použitia stratifikovaného výberu preukázali, že existuje priamy signifikantný vztảah medzi EI a životnou spokojnostou $(\mathrm{r}=.58 ; \mathrm{p}<.01)$ a medzi emocionálnou harmóniou a rezilienciou 
$(\mathrm{r}=.41, \mathrm{p}<.01)$. Navyše reziliencia vykazovala silnú vysoko významnú koreláciu so životnou spokojnostou $(\mathrm{r}=.60, \mathrm{p}<.01)$ ako aj s EI $(\mathrm{r}=.50, \mathrm{p}<.01)$. Vztảa črtovej EI, nádeje a životnej spokojnosti skúmali aj tureckí autori Saricam, Celik a Coskun (2015), kde ich výskumnú vzorku tvorilo 478 žiakov základných škôl (395 dievčat, priemerný vek respondentov bol 19.3). EI posudzovali Schutteovej škálou emocionálnej inteligencie (SEIS, 1998) a životnú spokojnost' Dienerovou škálou životnej spokojnosti (SWLS, 1985). Preukázali stredne silné pozitívne korelácie medzi sledovanými premennými $(\mathrm{r}=.47, \mathrm{p}<.01)$.

\section{Kroskultúrne porovnanie životnej spokojnosti a EI}

Na základe analýzy dostupných zdrojov predpokladáme, že existuje signifikantná súvislost' medzi rôznymi modelmi a konceptami EI a životnou spokojnostou jednotlivcov rôznych národností (Američania, Španieli, Turci, študenti z Iránu a i.), avšak nachádzame vel'mi málo vedeckých štúdií, ktoré by posudzovali súvislost' medzi nami zvoleným Petridesovým modelom črtovej EI (ako sme spomenuli vyššie len 1 štúdia je evidovaná v databáze WoS, november, 2019) a životnou spokojnostou. Zároveň existuje len niekol'ko štúdií, ktoré poukazujú na rozdiely v aspektoch črtovej EI a životnej spokojnosti v kros-kultúrnom kontexte. Záujem o hĺbkovú analýzu rozdielov v sledovaných premenných bol podnietený vedecko-výskumnými ambíciami projektu VEGA 1/0654/17, kde sme uvažovali nad interkultúrnou determináciou predovšetkým osobnostných predispozícií pri práci s emóciami, resp. emocionalitou, ako aj osobným záujmom študentky, Mariie Shevchenko, pochádzajúcej z Ukrajiny študujúcej na Pedagogickej fakulte Univerzity Mateja Bela v Banskej Bystrici, Slovensko. Dáta v uvedenej štúdii boli súčastou riešeného vedecko-výskumného zámeru jej práce (Shevchenko, 2019) a boli podrobené hlbším analýzam s jej súhlasom.

Pri stanovení výskumných predpokladov vychádzame zo štatistických ekonomických analýz a správ WHO (Atlas, 2011), pretože i to ako ludia hodnotia svoje životné podmienky, v akých podmienkach skutočne žijú má významný vplyv na ich spokojnost' so životom. Ukrajina je zaradená medzi krajiny s nižšími-strednými príjmami (lower-middle) v porovnaní so zaradením Slovenska ako krajiny s vysokými príjmami, čo taktiež ovplyvňuje životnú spokojnost' obyvatel'ov. Zároveň berieme do úvahy World Happiness Report (2018), kde sa dlhodobo Ukrajina javí ako krajina dokonca so zvyšujúcimi sa determinantami smútku, sklamania a neštastia $\mathrm{v}$ tejto krajine, za posledných 10 rokov (pokles o 1.03 boda) a zastávajú 138. pozíciu zo 156 krajín sveta. Ukrajina sa tak stáva „krajinou s najmenej štastnými obyvatel'mi“ (s hodnotou 4.10 v rozsahu 1-10, kde najvyššiu hodnotu dosiahli krajiny ako Fínsko [7.6], Nórsko [7.6], Dánsko, [7.5]) v Európe, v porovnaní so Slovákmi, ktorí sa umiestnili na 59. priečke (s hodnotou 6.2; Helliwell, Layard, \& Sachs, 2018).

Na druhej strane existuje len niekolko štúdií, ktoré diskutujú o komparáciách úrovne črtovej EI v interkultúrnom kontexte, ako sú štúdie s britskými respondentami, ktorí zaznamenali vyššie skóre v globálnej úrovni črtovej EI ako ich čínski kolegovia (Gökçen, Furnham, Mavroveli, \& Petrides, 2014), pričom francúzski respondenti nedosahovali 
v dotazníkoch črtovej EI - TEIQue vyššie hodnoty (ani v globálnej úrovni a ani v jednotlivých faktoroch) ako účastníci z pakistanskej vzorky (Karim, 2011).

\section{Výskumný problém a ciele výskumu}

Skúmanie vztahovov EI a životnej spokojnosti trvá už viac ako 2 desiatky rokov, kde aj napriek tomu, že to nie je nová výskumná téma stále prináša nové zistenia, v našom prípade, v kontexte špecifík kultúrneho prostredia. Uvedomujeme si, že životná spokojnost’ je konštrukt, ktorý reflektuje kultúrne, ekonomické a sociálne podmienky jednotlivcov.

Cielom našej štúdie sa stalo:

1. Zistit rozdiely v črtovej EI medzi vysokoškolákmi zo Slovenska a z Ukrajiny.

2. Zistit’ rozdiely $\mathrm{v}$ životnej spokojnosti medzi vysokoškolákmi zo Slovenska a z Ukrajiny.

3. Zistit’ vztahah črtovej EI a životnej spokojnosti u študentov zo Slovenska a Ukrajiny.

4. Zistit’ mieru predikcie životnej spokojnosti globálnou úrovňou črtovej EI a jej jednotlivých faktormi.

Vzhl'adom na to, že sa nám nepodarilo zachytit' uvedené premenné v obdobnom kros-kultúrnom kontexte, uprednostnili sme nasledujúce výskumné otázky:

VOl: Existuje štatisticky významný rozdiel v globálnej úrovni črtovej EI a jej faktoroch medzi vysokoškolákmi zo Slovenska a z Ukrajiny?

VO2: Existuje štatisticky významný rozdiel v životnej spokojnosti medzi vysokoškolákmi zo Slovenska a z Ukrajiny?

VO3: Súvisí globálna úroveň črtovej EI a jej faktorov so životnou spokojnostou v dvoch súboroch vysokoškolákov?

VO4: Do akej miery je možné predikovat úroveň životnej spokojnosti globálnou úrovňou črtovej EI u slovenských a ukrajinských vysokoškolákov?

VO5: Ktorý z faktorov črtovej EI je signifikantným prediktorom životnej spokojnosti slovenských a ukrajinských vysokoškolákov?

\section{Výskumný súbor}

Výskumný súbor pozostával zo 193 vysokoškolských študentov vo veku od 18 do 26 rokov. Počet slovenských respondentov bol 100 ( $\sim 51.8 \%)$, a ukrajinských 93 ( 48.2\%). Slovenský súbor tvoria študenti Univerzity Mateja Bela v Banskej Bystrice (26 \% mužov) a ukrajinská skupina bola tvorená študentmi z rôznych kyjevských vysokých škôl (47.3 \% mužov). Priemerný vek bol v skupine slovenských vysokoškolákov 20.08 (SD=1.41) a v ukrajinskej skupine $21.55(\mathrm{SD}=2.80)$. Použili sme dostupný výber. 


\section{Výskumné metodiky}

Na meranie črtovej EI sme použili Petridesov dotazník črtovej EI a jeho krátku formu pre dospelých (Trait Emotional Intelligence Questionnaire-Short Form - TEIQue-SF, Petrides, 2009). Dotazník pozostáva z 30 položiek, na ktoré respondent vyjadruje mieru súhlasu pomocou 7-stupňovej Likertovej škály. Skrátená verzia umožňuje vyčíslit’ globálnu úroveň črtovej EI ako aj skúmat’ jej štyri faktory (sociabilitu, emocionalitu, sebakontrolu, well-being), ale len pre výskumné účely. TEIQue-SF sa javí v medzinárodnom ako aj v slovenskom kontexte ako psychometricky akceptovatel'ný nástroj (Petrides, 2009; Kaliská \& Nábělková, 2015; Kaliská, Nábělková, \& Salbot, 2015). V tejto štúdii sa taktiež potvrdili akceptovatel'né hodnoty vnútornej konzistencie pre oba súbory (Cronbachova alfa pre celý výskumný súbor: Ukrajinci: $\alpha=.90$ [.93 ženy; .85 muži]; Slováci: $\alpha=.80$ [.83 ženy; .68 muži]).

Na zistovanie životnej spokojnosti sme použili Škálu životnej spokojnosti (The Satisfaction With Life Scale - SWLS), autorov Diener, Emmnos, Larsen a Griffin (1985). Dotazník pozostáva z 5 položiek, na ktoré respondent odpovedá prostredníctvom 7-stupňovej škály súhlasu - nesúhlasu, a zistuje jednu dimenziu - celkové skóre životnej spokojnosti. Podl’a autorov je Škála životnej spokojnosti orientovaná na meranie kognitívneho komponentu celkovej životnej spokojnosti respondenta. Možno ju používat' v širokom spektre skupín. SWLS sa javí ako validný a reliabilný nástroj na meranie životnej spokojnosti (Pavot, Diener, Colvin, \& Sandvik, 1991; Pavot \& Diener, 1993). V našom výskumnom súbore SWLS dosahuje akceptovatel'né hodnoty vnútornej konzistencie (Cronbachova alfa pre celý výskumný súbor: Ukrajinci: $\alpha=.86$ [.87 ženy; .86 muži]; Slováci: $\alpha=.83$ [.86 ženy; .63 muži]).

Verzie dotazníkov pre ukrajinských respondentov boli preložené do ruštiny (v Kyjeve väčšina obyvatel'ov využíva ruský jazyk). Preklad dotazníkov sme zabezpečili dvomi nezávislými odborníkmi a na základe nich sme vytvorili finálne verzie našich výskumných nástrojov.

\section{Výsledky výskumu}

V tab.l uvádzame deskriptívne charakteristiky pre oba výskumné súbory.

Tabul'ka 1

Deskriptivne ukazovatele sledovaných premenných

\begin{tabular}{|c|c|c|c|c|c|c|c|c|c|}
\hline \multirow{7}{*}{ 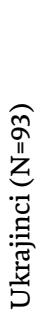 } & \multirow{6}{*}{ 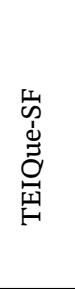 } & & Min & Max & MDN & AM & SD & Šikmost' & Strmost' \\
\hline & & Well-being & 2.50 & 7.00 & 5.42 & 5.26 & .97 & -.788 & .484 \\
\hline & & Seba-kontrola & 2.00 & 6.83 & 4.50 & 4.40 & .94 & -.312 & .132 \\
\hline & & Emocionalita & 2.38 & 6.75 & 5,25 & 5.17 & .81 & -.666 & 2.38 \\
\hline & & Sociabilita & 2.33 & 6.83 & 4.67 & 4.52 & .82 & -.115 & -.063 \\
\hline & & Globálna črtová EI & 3.20 & 6.63 & 4.83 & 4.82 & .61 & -.021 & -.060 \\
\hline & SWLS & Životná spokojnost' & 5.00 & 35.00 & 21.00 & 19.73 & 7.38 & -.225 & -.926 \\
\hline
\end{tabular}




\begin{tabular}{|c|c|c|c|c|c|c|c|c|c|}
\hline \multirow{6}{*}{ 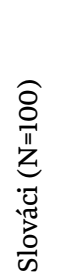 } & \multirow{5}{*}{ 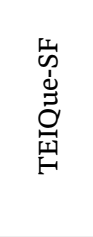 } & Well-being & 1.33 & 7.00 & 5.17 & 4.94 & 1.21 & -.501 & -.473 \\
\hline & & Seba-kontrola & 2.17 & 6.50 & 4.67 & 4.48 & 1.00 & -.473 & -.349 \\
\hline & & Emocionalita & 2,38 & 7.00 & 5.13 & 4.97 & .94 & -.761 & .594 \\
\hline & & Sociabilita & 1.83 & 7.00 & 5.00 & 4.65 & 1.14 & -.492 & -.242 \\
\hline & & Globálna črtová EI & 2.37 & 6.50 & 4.83 & 4.74 & .87 & -.674 & .157 \\
\hline & SWLS & Životná spokojnost’ & 5.00 & 35.00 & 21.00 & 19.73 & 7.38 & -.225 & -.926 \\
\hline
\end{tabular}

Pozn. Min - minimum, Max - maximum, MDN - medián, AM- aritmetický priemer, SD - smerodajná odchýlka

Na základe koeficientov šikmosti a strmosti konštatujeme, že dáta spĺňajú podmienku normálneho rozloženia, čo umožňuje využit parametrické testy na zodpovedanie stanovených výskumných otázok.

VOl: Existuje štatisticky významný rozdiel v globálnej úrovni črtovej EI a jej faktoroch medzi vysokoškolákmi zo Slovenska a z Ukrajiny?

VO2: Existuje štatisticky významný rozdiel v životnej spokojnosti medzi vysokoškolákmi zo Slovenska a z Ukrajiny?

Uvedené výskumné otázky sme analyzovali pomocou t-testu pre dva nezávislé výbery, kde sa posudzoval rozdiel $\mathrm{v}$ priemeroch dvoch skupín. Uvedené zistenia sme doplnili vyčíslením Cohenovho d-indexu, ktorý predstavuje vecnú (praktickú) významnost' rozdielov. Zistenia sú prezentované v tab. 2.

\section{Tabul'ka 2}

Analýza rozdielov v črtovej EI a jej faktoroch a celkovej životnej spokojnosti medzi vysokoškolákmi z Ukrajiny a zo Slovenska

\begin{tabular}{|c|c|c|c|c|c|c|c|c|}
\hline & & Min & Max & $\mathrm{AM}$ & SD & Median & t-test & d-index \\
\hline \multirow{5}{*}{ 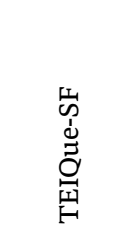 } & Well-being & 1.33 & 7.00 & 4.94 & 1.21 & 5.17 & $2.02^{\star}$ & .29 \\
\hline & Seba-kontrola & 2.17 & 6.50 & 4.48 & 1.00 & 4.67 & -.62 & .08 \\
\hline & Emocionalita & 2.38 & 7.00 & 4.97 & .94 & 5.13 & 1.59 & .23 \\
\hline & Sociabilita & 1.83 & 7.00 & 4.65 & 1.14 & 5.00 & -.93 & .13 \\
\hline & Globálna črtová EI & 2.37 & 6.50 & 4.74 & .87 & 4.83 & .73 & .11 \\
\hline SWLS & Životná spokojnost’ & 5.00 & 35.00 & 19.73 & 7.38 & 21.00 & $2.68^{* *}$ & .39 \\
\hline & Well-being & 2.50 & 7.00 & 5.26 & .97 & 5.42 & & \\
\hline & Seba-kontrola & 2.00 & 6.83 & 4.40 & .94 & 4.50 & & \\
\hline $\bar{w}$ & Emocionalita & 2.38 & 6.75 & 5.17 & .81 & 5.25 & & \\
\hline ర్య & Sociabilita & 2.33 & 6.83 & 4.52 & .82 & 4.67 & & \\
\hline H & Globálna črtová EI & 3.20 & 6.63 & 4.82 & .61 & 4.83 & & \\
\hline SWLS & Životná spokojnost’ & 9.00 & 35.00 & 22.35 & 6.07 & 23.00 & & \\
\hline
\end{tabular}

Pozn. ${ }^{*} \mathrm{p} \leq 0,05 ;{ }^{* *} \mathrm{p} \leq 0,01 \mathrm{Min}$ - minimum, Max - maximum, AM - aritmetický priemer, SD - Standard deviation 
Analýza dát preukázala existenciu signifikantného rozdielu v celkovej životnej spokojnosti (takmer na hranici strednej vecnej významnosti, $0.50 \leq \mathrm{d}<0.80$ in Cohen, 1988), kde vyššie skórovali slovenskí študenti. Zároveň dosiahli i signifikantne vyššiu úroveň well-beingu, resp. subjektívnej pohody, avšak s nízkymi efektom rozdielu ( $\mathrm{d}<0.50$ in Cohen, 1988).

Zároveň je možné konštatovat’ na základe nami vytvorených slovenských noriem pre obdobie vynárajúcej sa dospelosti (normalizačný súbor: $N=1264$, priemerný vek =21.2), že slovenský výskumný súbor dosahuje 47. percentil (Kaliská et al., 2019, s. 78).

VO3: Súvisí globálna úroveň črtovej EI a jej faktory so životnou spokojnostou v slovenskej a ukrajinskej vzorke vysokoškolákov?

Ďalším výskumným cielom bolo identifikovat’ súvislosti medzi celkovou životnou spokojnostou študentov dvoch rôznych výskumných súborov a aspektov črtovej EI pomocou Pearsonovej štatistickej korelačnej analýzy, kde výsledky ponúkame v tab. 3.

Tabul'ka 3

Korelácie medzi celkovou životnou spokojnostou a globálnou úrovňou črtovej EI a jej faktormi v dvoch výskumných súboroch

\begin{tabular}{lll}
$\begin{array}{l}\text { Črtová EI } \\
\text { (TEIQue-SF) }\end{array}$ & \multicolumn{2}{l}{ Životná spokojnost’ (SWLS) } \\
\hline Well-being & Vysokoškoláci UKR & Vysokoškoláci SVK \\
\hline Sebakontrola & $.722^{* * *}$ & $.639^{* * *}$ \\
\hline Emocionalita & $.502^{* * *}$ & $.309^{* * *}$ \\
\hline Sociabilita & $.429^{* * *}$ & .022 \\
\hline Globálna EI & $.532^{* * *}$ & $.200^{*}$ \\
\hline
\end{tabular}

Pozn. * $\mathrm{p} \leq 0,05 ;{ }^{* * *} \mathrm{p} \leq, 001$

Globálna úroveň črtovej EI vstupuje do vysoko signifikantného silného vztahu s celkovou životnou spokojnost’ou, s výraznejšou prevahou súvislostí jednotlivých faktorov a celkovej EI u vysokoškolákov z Ukrajiny. V súbore slovenských vysokoškolákov sme nezaznamenali súvislosti s faktorom emocionality a slabý vzt̉ah $\mathrm{s}$ faktorom sociability.

VO4: Do akej miery je možné predikovat úroveň životnej spokojnosti globálnou úrovňou črtovej EI u slovenských a ukrajinských vysokoškolákov?

VO5: Ktorý z faktorov črtovej EI je signifikantným prediktorom životnej spokojnosti slovenských a ukrajinských vysokoškolákov?

Ďalším cielom sa tak stalo predikovanie úrovne celkovej životnej spokojnosti študentov na základe ich celkovej úrovne črtovej EI (tab. 4), ako aj jednotlivými faktormi črtovej EI (Tab.5). 
Tabul'ka 4

Lineárná analýza globálnej črtovej EI pre závislú premennú celkovú životnú spokojnost'

\begin{tabular}{lllllll} 
& $\mathrm{R}$ & $\mathrm{R}^{2}$ & $\mathrm{R}_{\text {adj }}$ & $\mathrm{F}$ & $\mathrm{p}$ & $\beta$ \\
\hline UKR & .690 & .476 & .470 & 82.633 & .000 & .690 \\
SVK & .457 & .209 & .201 & 25.938 & .000 & .457
\end{tabular}

Pozn. R - korelačný koeficient, $\mathrm{R}^{2}$ - koeficient determinácie, $\mathrm{R}^{2}{ }_{\text {adj }}$ - upravený koeficient determinácie, $\mathrm{F}$ - hodnota F-testu, p - štatistická významnost' F-testu, $\beta$ - Beta koeficient

Celková úroveň črtovej EI posúdená dotazníkom TEIQue-SF signifikantne predikuje do istej miery celkovú životnú spokojnost’ v oboch výskumných súboroch. V súbore ukrajinských študentov, črtová EI vysvetl'uje vyššiu mieru variancie rozptylu až do $47 \%$ $(\mathrm{F}[1,91]=82.63, \mathrm{p} \leq .001)$, kým v skupine slovenských študentov to bolo do $20 \%$ (F [1,99] = 25.94, $\mathrm{p} \leq .001$ ). Upravený koeficient determinácie a koeficient determinácie sa významne nelíšili v miere predikovania variability celkovej životnej spokojnosti v oboch prípadoch.

Následne nás zaujímalo do akej miery jednotlivé faktory črtovej EI predikujú celkovú životnú spokojnosť študentov z dvoch rôznych kultúrnych prostredí (tab. 5).

Tabul'ka 5

Regresná analýza faktorov črtovej EI pri závislej premennej celkovej životnej spokojnosti v dvoch výskumných súboroch

\begin{tabular}{|c|c|c|c|c|c|c|c|c|}
\hline \multirow[b]{2}{*}{ Model PTSD } & \multicolumn{4}{|c|}{ Vysokoškoláci UKR } & \multicolumn{4}{|c|}{ Vysokoškoláci SVK } \\
\hline & Beta-koef. & $\mathbf{T}$ & $\mathbf{p}$ & Par. kor. & Beta-koef. & $\mathbf{T}$ & $\mathrm{p}$ & Par. kor. \\
\hline 1 (konštanta) & & -1.52 & .133 & & & .512 & .610 & \\
\hline Well-being & .612 & 6.32 & .000 & $.559 * * *$ & .587 & 6.68 & .000 & $.566^{* * *}$ \\
\hline Seba-kontrola & .023 & .23 & .818 & .025 & .143 & 1.56 & .122 & .158 \\
\hline Emocionalita & -.017 & -.182 & .856 & -.019 & -.074 & -.913 & .364 & -.093 \\
\hline Sociabilita & .195 & 1.94 & .056 & .203 & -.007 & -.084 & .933 & -.009 \\
\hline
\end{tabular}

Pozn. ${ }^{* * *} \mathrm{p} \leq .001$, Beta-koef. - Beta koeficienty, par. kor. - parciálne korelácie

Pomocou regresnej analýzy, kde nezávislými premennými boli faktory črtovej EI (well-being, sebakontrola, emocionalita, sociabilita), sme predikovali mieru závislej premennej celkovej životnej spokojnosti respondentov $\mathrm{z}$ dvoch rôznych kultúrnych prostredí. Preukázali sme, že jedine faktor well-beingu, t.j. duševnej pohody a spokojnosti vysoko významne predikuje ( $\mathrm{p} \leq .001)$ mieru celkovej životnej spokojnosti v oboch výskumných súboroch. Zároveň pri kontrole ostatných premenných/faktorov črtovej EI, jedine faktor well-beingu vstupuje do vysoko významného stredne silného pozitívneho vztahu s celkovou životnou spokojnostou v oboch výskumných súboroch.

\section{Diskusia}

Ciel'om predkladanej výskumnej štúdie bola analýza aspektov črtovej EI a životnej spokojnosti vysokoškolákov pochádzajúcich $\mathrm{z}$ dvoch rôznych kultúrnych a spoločensko-ekonomických prostredí. Črtová EI ako aj dotazníky na jej meranie sa dlhodobo javia 
ako dostatočne validné i reliabilné v slovenskom (Kaliská \& Nábělková, 2015; Kaliská et al., 2015; Kaliská et al., 2019) ako i zahraničnom prostredí (Petrides, 2009), kde umožňujú spolahlivo predikovat’ osobnostné predispozície súvisiace s emóciami, resp. emocionalitou. Slovenské štandardizované verzie či už dlhej ako aj krátkej formy radu dotazníkov TEIQue sú odobrené i samotným autorom koncepcie črtovej EI (http://psychometriclab. com/translations-of-teique/). V tejto štúdii sa opätovne potvrdzuje, že skrátená verzia dotazníka na meranie črtovej EI u slovenskej vzorky, ale zároveň aj u ukrajinskej vzorky, dosahuje vysoko akceptovatel'né ukazovatele reliability v zmysle vnútornej konzistencie nástroja. Verifikovanie základných vlastností ukrajinskej i ruskej verzie dotazníka nie je ešte dostatočne vedecko-výskumne potvrdené a tak táto štúdia naznačuje možnosti d’alšieho overovania a etablovania dotazníkov radu TEIQue v novom kultúrnom prostredí (overená verzia ukrajinského a ani ruského dotazníka TEIQue ešte nie je uverejnená na stránke autora modelu i dotazníkov, http://psychometriclab.com/translations-of-teique/), čo ponúka d'alšiu možnost' výskumu.

Cielom hlbšej analýzy sa stali jednak emocionálne predispozície jednotlivcov $\mathrm{z}$ rôznych kultúrnych a socio-ekonomických prostredí $\mathrm{v}$ súvislosti $\mathrm{s}$ ich prežívanou a hodnotenou životnou spokojnostou, predovšetkým jej kognitívnymi komponentmi. Sám autor nami použitej škály SWLS deklaruje, že subjektívna pohoda ako dlhodobo pretrvávajúci emocionálny stav preukazuje celkovú spokojnost́ človeka s jeho vlastným životom (Diener \& Suh, 1997), ktorá je determinovaná emocionálnymi prejavmi, ale aj kognitívnym porozumením spokojnosti ako takej. Porozumenie zmysluplnosti vlastnej existencie ako základný komponent l’udského života (Baumeister, 1991) sa tak stal fundamentálny pre zameranie i našich možných východísk v konceptualizácii črtovej emocionálnej inteligencie.

Analýza rozdielov v črtovej EI medzi študentmi z Ukrajiny a Slovenska potvrdila významný rozdiel vo faktore well-being z modelu črtovej EI, kde nižšie skórovali študenti pochádzajúci z Ukrajiny a zároveň významný rozdiel v celkovej životnej spokojnosti, kde vyššie skórovali študenti zo Slovenska. Niekol'kokrát bolo výskumne preukázané (o.i. aj autorom modelu životnej spokojnosti), že existuje súvislost’ medzi finančným zabezpečením a subjektívnou pohodou jednotlivcov (napr. v USA, Diener \& Biswas-Diener, 2002). Naše zistenia tak podporujú predpoklad, že vysokoškoláci z Ukrajiny patria medzi menej št’astných obyvatel'ov EU (Helliwell et al., 2018), čo aj vysvetluje ich záujem študovat' v iných kultúrnych prostrediach, napr. na Slovensku (na 5. mieste podla štatistík UNESCO, 2020) a v Čechách (na 3. mieste podl’a štatistík UNESCO, 2020). Konštatujeme však, že oba rozdiely dosiahli len nízku vecnú významnost', čo skôr poukazuje na isté tendencie v rozdieloch v sledovaných premenných.

Hlbšia analýza súvislostí medzi sledovanými premennými, t.j. medzi celkovou životnou spokojnostou a aspektmi črtovej EI, preukázala v obidvoch súboroch štatisticky signifikantné, stredne silné až silné súvislosti s celkovou úrovňou črtovej EI predovšetkým u ukrajinských študentov. V prípade slovenského súboru jedine faktor emocionality nevstupoval do súvislostí so životnou spokojnostou. Vysvetlit túto skutočnost' môžeme tak, že faktor emocionality zahŕňa také komponenty ako empatia, vlastná percepcia 
a expresia emócií a vztahová kompetencia, kde vnímanie a riadenie vlastných emócií a uvedomovanie si vlastnej kompetencie pri vytváraní si vztahov nemusí významne súvisiet práve s kognitívnym uvedomovaním si osobnej spokojnosti. Pozoruhodné súvislosti boli preukázané medzi faktorom well-beingu a životnej spokojnosti v obidvoch súboroch vysokoškolákov, kde obe súvislosti boli vysoko štatisticky významné a silné ( $\mathrm{r}=.722$, $\mathrm{p} \leq .000$ ukr., $\mathrm{r}=.639, \mathrm{p} \leq .000$ sl.). Faktor well-beingu sa zároveň stal jediným významným prediktorom životnej spokojnosti v oboch súboroch, kde vysoko významný silný vztah bol zachovaný medzi týmito sledovanými premennými i po kontrole ostatných faktorov črtovej EI. Faktor well-beingu v koncepcii Petridesa (2009) zahŕňa pohodu, pocit štastia, osobný optimizmus, naplnenost’ a zároveň i primeranú mieru vlastného sebahodnotenia. Práve tieto zložky Diener, Suh, Lucas a Smith (1999) predstavili ako základné faktory determinujúce subjektívnu pohodu. Konkrétne celkovú životnú spokojnost' (Diener \& Suh, 1997), štastie v kontexte procesu nie ako konečný ciel', ale žiaduci a kladný emocionálny stav, ktorý sa zjaví po naplnení našich túžob pri priaznivých podmienkach, a v neposlednej miere tak patrí i sebahodnotenie, to ako vnímame samých seba. Naše výsledky tak korešpondujú s inými výskumami realizovanými v rôznych krajinách napr. Palmera, Donaldsona a Stougha (2002); Extremera a Fernández-Berrocala (2005); Runcana a Iovua (2013); Urquijoa, Extremera a Villa (2015); Foumanya a Salehya (2015); Saricama, Celika a Coskun (2015) a inými.

Ako sme sa už zmienili výskumný potenciál vidíme v d’alšom overovaní základných vlastností ukrajinskej verzie dotazníkov TEIQue, ako i zameranie sa na overenie potenciálnych mediátorov vztahu životnej spokojnosti a EI. Hlavným limitom príspevku je rozsah výskumného súboru, ale i nerovnomerné rodové zastúpenie respondentov.

\section{Záver}

Potvrdili sme všeobecne preukázaný vzţah medzi črtovou emocionálnou inteligenciou a životnou spokojnostou. Vychádzajúc z odborných zdrojov ako i z našich výskumných zistení konštatujeme, že črtová EI a predovšetkým jej faktor well-beingu sa javí ako významný prediktor životnej spokojnosti. Znamená to tiež, že o tom, do akej miery je človek spokojný so svojim životom, rozhodujú aj osobnostné pr emenné. Pozitívne emocionálne vyladenie osobnosti ovplyvňujú i sociálne a ekonomické podmienky, ktoré sa všeobecne považujú za dôležité aspekty životnej spokojnosti. Zdá sa však, že kultúrne a ekonomické podmienky nemusia byt’ jediným rozhodujúcim činitel’om životnej spokojnosti jednotlivca. Podpora a zámerné facilitovanie emocionálnej inteligencie a jej jednotlivých súčastí môže zohrat' dôležitú úlohu v oblasti životnej spokojnosti, čo nesie v sebe preventívny potenciál ochrany duševného zdravia jednotlivca. Psychológovia facilitujúci emocionálne predispozície jednotlivca sa tak stávajú dôležitou súčastou podpory duševne zdravej vyvíjajúcej sa spoločnosti. Sekundárnym výsledkom našej štúdie je aj potvrdenie konvergentnej validity dotazníka črtovej emocionálnej inteligencie (TEIQue-SF) vo vzțahu k životnej spokojnosti, čo však otvára d'alšie výskumné otázky zamerané na d’alší proces validizácie (napr. na overovanie obsahovej a tzv. „zjavnej“ (face) validity). 


\section{Referencie}

Baumeister, R. F. (1991). Meanings of life. New York: Guilford Press.

Cohen, J. (1988). Statistical Power Analysis For The Behavioral Science (2nd Ed.). Hillsdale (NJ): Erlbaum.

Diener, E. (1994). Asseing subjective well-being: Progress and opportunities. Social Indicators Research, 31, 103-157.

Diener, E. (2000). Subjective well-being. American Psychologist, 55(1), 34-43.

Diener, E., \& Biswas-Diener, R. (2002). Will money increase subjective well-being: a literature review and guide to needed research. Social Indicators Research, 57, 119-169.

Diener, E., \& Suh, E. (1997). Measuring quality of life: Economic, social and subjective indicators. Social indicators research, 40, 189-216.

Diener, E., Suh, E. M., Lucas, R. E., \& Smith, H. L. (1999). Subjective well-being: Three decades of progress. Psychological Bulletin, 125(2), 276-302.

Diener, E., Emmons, R. A., Larsen, J., \& Griffin, S. (1985). The satisfaction with life scale. Journal of Personality Assessment, 49(1), 71-75. https://doi.org/10.1207/s15327752jpa4901_13

Diener, E., Scollon, CH., \& Lucas, R. E. (2004). The evolving concept of subjective well-being: The multifaced nature of happiness. In Costa, P. T. \& Siegler, I. C. (eds.), Advances in cell aging and gerontology (s. 187-220). Amsterdam: Elsevier.

Džuka, J., \& Dalbert, C. (2002). Vývoj a overenie validity škál emocionálnej habituálnej subjektívnej pohody (SHEP). Československá psychologie, 46(3), 234-250.

Džuka, J., \& Dalbert, C. (2006). The belief in a just world and subjective well-being in old age. Aging and Mental Health, 10, 439-444. https://doi.org/10.1080/13607860600637778

Ellison, C.G. (1991). Religious involvement and subjective well-being. Journal of Health and Social Behavior, 32, 80-99. https://doi.org/10.2307/2136801

Extremera, N., \& Fernández-Berrocal, P. (2005). Perceived emotional intelligence and life satisfaction: Predictive and incremental validity using the Trait-Meta-Mood-Scale. Personality and Individual Differences, 39(5), 937-948. https://doi.org/10.1016/j.paid.2005.03.012

Fahrenberg, J. (1994). Die Freiburger Beschwerdenliste (FBL) Form FBL-G und revidierte Form FBL-R. Göttingen: Hogrefe.

Foumany, G. H. E., \& Salehi, J. (2015). The relationship beetwen emotional intelligence and life satisfaction and the mediatory role of resiliency and emotional balance among the students of Zanjan university. Acta medica mediterranea, 31(2), 1351-1357.

Gökçen, E., Furnham, A., Mavroveli, S., \& Petrides, K. V. (2014). A cross-cultural investigation of trait emotional intelligencein Hong Kong and the UK. Personality and Individual Differences, 65, 30-35. https://doi.org/10.1016/j.paid.2014.01.053

Helliwell, J., Layard, R., \& Sachs, J. (2018). World happiness report 2018. New York: Sustainable Development Solutions Network.

Kaliská, L., \& Nábělková, E. (2015). Psychometrické vlastnosti a slovenské normy Dotazníkov črtovej emocionálnej inteligencie pre deti, adolescentov a dospelých. Banská Bystrica: Belianum.

Kaliská, L., Heinzová, Z., \& Nábělková, E. (2015). Dotazníky črtovej emocionálnej inteligencie TEIQue-SF/ TEIQue-CSF: manuál k skráteným formám (2. čast'). Banská Bystrica: Belianum.

Kaliská, L., Nábělková, E., \& Salbot, V. (2019). Dotazníky črtovej emocionálnej inteligencie TEIQue-SF/ TEIQue-CSF: manuál k skráteným formám. Banská Bystrica: Belianum.

Karim, J. (2011). Emotional Intelligence: A Cross-Cultural Psychometric Analysis (dizertačná práca, Universite de Paul Cezanne, Aix-en-Provence and Marseille, France). Získané $\mathrm{z}$ https://www.theses. fr > 2011AIX32028

Kluemper, D. H. (2008). Trait Emotional Intelligence: The impact of Core-self Evaluations and Social Desirability. Personality and Individual Differences, 44, 1 402-1 412. https://doi.org/10.1016/j. paid.2007.12.008 
Palmer, B., Donaldson, C., \& Stough, C. (2002). Emotional intelligence and life satisfaction. Personality and Individual Differences, 33(7), 1 091-1 100. https://doi.org/10.1016/S0191-8869(01)00215-X

Pavot, W. G., \& Diener, E. (1993). Review of the Satisfaction with Life Scale. Psychological Assessment, 5, 164-172.

Pavot, W. G., Diener, E., Colvin, C. R., \& Sandvik, E. (1991). Further validation of the Satisfaction with Life Scale: Evidence for the cross-method convergence of well-being measures. Journal of Personality Assessment, 57, 149-161. doi: 10.1207/s15327752jpa5701_17

Petrides, K. V. (2009). Trait Emotional Intelligence Questionnaire (TEIQue). Technical Manual. London: London Psychometric Laboratory.

Petrides, K. V., Pérez-González, J. C., \& Furnham, A. (2007). On the criterion and incremental validity of trait emotional intelligence. Cognition and Emotion, 21(1), 26-55. https://doi. $\operatorname{org} / 10.1080 / 02699930601038912$

Petrides, K. V., Pita, R., \& Kokkinaki, F. (2007). Thelocation of trait emotional intelligencein personality factor space. British Journal of Psychology, 98, 273-289. https://doi.org/10.1348/000712606X120618

Runcan, P. L., \& Iovu, M. B. (2013). Emotional Intelligence and life satisfaction in Romanian university students: The mediating role of self-esteem and social suport. Revista de cercetare si interventie socialia, 40, 137-148.

Russo, P. M., Mancini, G., Trombini, E., Baldaro, B., Mavrovelli, S., \& Petrides, K. V. (2012). Trait Emotional Intelligence and the Big Five: A Study on Italian Children and Preadolescents. Journal of Psychoeducational Assessment, 30(3), 274-283. https://doi.org/10.1177/0734282911426412

Salovey, P., \& Mayer, J. (1990). Emotional Intelligence. New York: Baywood Publishing.

Saricam, S., Celik, I., \& Coskun, L. (2015). The relationship between emotional intelligence, hope and life satisfaction. Educational research association. The international journal of research in teacher education, 6(1), 1-9.

Shevchenko, M. (2019). Kroskultúrny výskum vztahu črtovej emocionálnej inteligencie a životnej spokojnosti (bakalárska práca, Univerzita Mateja Bela, Banská Bystrica, Slovensko).

Schutte, N. S., Malouff, J. M., Hill, L. E., Haggerty, D. J., Cooper, J. T., Golden, Ch. J., \& Dornheim, L. (1998). Development and validation of a Measure of Emotional Intelligence. Personality and Individual Differences, 25, 167-177. https://doi.org/10.1016/S0191-8869(98)00001-4

UNESCO Institute for Statistics (2020). Global Flow of Tertiary-Level Students. Získané z: http://uis. unesco.org/en/uis-student-flow

Urquijo, I., Extremera, N., \& Villa, A. (2015). Emotional intelligence, life satisfaction, and psychological well-being in graduates: the mediating effect of perceived stress. Applied research in quality of life, 1-15.

Watson, D., Clark, L., \& Tellegen, A. (1988). Development and validation of brief measures of positive and negative affect: The PANAS scales. Journal of Personality and Social Psychology, 54, 1 063-1 070. https://doi.org/10.1037//0022-3514.54.6.1063

Wong, C. S., \& Law, K. S. (2002). The effects of leader and follower emotional intelligence on performance and attitude: An exploratory study. The Leadership Quarterly, 13(3), 243-274. https://doi. org/10.1016/S1048-9843(02)00099-1

WHO (2019). The WHO special initiative for mental health (2019-2023): universal health coverage for mental health. Získané z: https://apps.who.int/iris/handle/10665/310981

WHO(2015).TheEuropeanMentalHealthActionPlan2013-2020.Získanéz: https://www.euro.who.int/ data/assets/pdf_file/0020/280604/WHO-Europe-Mental-Health-Acion-Plan-2013-2020.pdf

Korespondenční autorka: Lada Kaliská, Katedra psychológie, Pedagogická fakulta, Univerzita Mateja Bela, Ružová 13, Banská Bystrica 974 11, Slovenská republika. E-mail: lada.kaliska@umb.sk

Kaliská, L., Pašková, L., \& Salbot, V. (2020). Črtová emocionálna inteligencia a životná spokojnost' vysokoškolákov - kroskulturálny výskum (Slováci vs. Ukrajinci). Psychologie a její kontexty, 17(2), 55-71. https://doi.org/10.15452/PsyX.2020.11.0010 